Larisa I. Zakharova*

Timur E. Melnik*:*

\title{
SOME REFLECTIONS ON REGULATING PROFESSIONAL SPORTS IN INTEGRATION ASSOCIATIONS: A SPHERE OF AUTONOMY OR AN OBJECT OF THE UNION LAW REGULATION?
}

\begin{abstract}
The regulation of relations in the field of sports is characterized by the presence of the considerable rule-making powers of sports federations that ensure the development of a particular sport, which is a manifestation of such a phenomenon as the autonomy of sport. States have to take into account this parallel normative reality. The issue of sport autonomy is gaining a new dimension in connection with the emergence of interstate integration associations, as there is a need to determine the relationship between the law of integration associations and the normative order established by sports federations, both national and international.

The law of integration associations as interpreted by their judicial institutions plays a significant role in defining the concept of sport autonomy, determining the scope of rule-making powers of sports federations and the boundaries of state regulation in the field of sports. First of all, this influence can be traced in the field of labour law. In many respects the decisions of the courts of such integration associations as the European Union (EU) and the Eurasian Economic Union (EAEU) shaped the modern approaches
\end{abstract}

* Associate Professor of the Kutafin Moscow State Law University (Russia), PhD in International Law, ORCID: 0000-0003-4968-0134, Email: lizakharova@msal.ru

** Researcher of the Institute of Legislation and Comparative Law under the Government of the Russian Federation, ORCID 0000-0001-5901-0789, Email: melnikte@ gmail.com 
to the content of the legal model of regulating the work of foreign athletes, taking into consideration such important principles as the freedom of movement of workers and the equality of labour rights for all citizens from the Member States of an integration association.

When interpreting the rules governing professional sports activities, the courts of integration associations distinguish between issues in which the sport movement retains its autonomy and the labour (economic) activities of athletes, which are subject to the legislation of the Union. The Court of Justice of the European Union (the CJEU) in its decisions has repeatedly voiced its opinion both on the autonomy of sport and on various aspects of economic activities of athletes and sports organizations. The Court of the Eurasian Economic Union (the EAEU Court) is a much younger court and it has not adjudicated on these issues so far. However, in December, 2018 it rendered its first advisory opinion on the labour activities of professional athletes who are citizens of the EAEU Member States, in which it followed the logic the CJEU had demonstrated in a well-known decision in the Bosman case.

\section{Keywords}

sports law - sports federations - autonomy of sport - integration associations - the CJEU - the EAEU Court

\section{INTRODUCTION}

The indisputable primacy of regulation carried out by national and international sports organizations represents a distinctive feature of regulating the sphere of sports. Historically, it was aimed at developing competition rules for a particular sport, "Long before the adoption of laws on sports and, moreover, the legal systematization in this area, people already ran races and overcame obstacles, competing with each other. And even then there were rules that determined the height of the jump, the length of the treadmill, and the requirements for holding competitions" ${ }^{1}$ States do not interfere in the regulation of training and

1 Ph. Jestaz, "Spectacle sportif et droit du sport", Le spectacle sportif, publication de la Faculté de Droit et des Sciences Economiques de l'Université de Limoges; Centre de Droit et d'Economie du Sport, Paris: PUF, 1981, p. 315. Cited in I. Ponkin, A. Ponkina, "O korrelyatsii lex sportiva i sportivnogo prava" ("On the correlation between lex sportiva 
competition relations - the so-called "core of sports". ${ }^{2}$ This peculiarity is called the autonomy (self-regulation) of sport. These norms are created as a result of self-regulation, not the legal regulation carried out by States, and they are transnational by their nature. ${ }^{3}$

The need for legal assistance from States to the sports community becomes noticeable in such areas as the fight against crime in the sports sphere (bringing to administrative or criminal responsibility for matchfixing and other forms of manipulating sports results, hooliganism of sports fans, etc.). ${ }^{4}$ Quite often, the State intervenes after certain rules of conduct have already been established within the framework of international sports organizations. ${ }^{5}$ Even though the state regulation begins to take shape later than the regulation within sports organizations, the inclusion of the State in the process of regulating professional sports inevitably leads to the redistribution of their rule-making powers (ideally, the legal regulation of the State in this sphere should remain supplementary and subsidiary in character). ${ }^{6}$

and sports law"), Vestnik RUDN, Seriya Yuridicheskiye nauki (Bulletin of the Peoples' Friendship University of Russia, Series of Legal Sciences), 2012, Issue 3, p. 110.

2 S. Yurlov, "Razvitie pravovoy nauki v chasti issledovaniya voprosov, svyazannyh s normativnym regulrovaniem sporta" ("Development of legal science in terms of research on issues related to the regulation of sports"), Vestnik Sankt-Peterburgskogo Universiteta. Pravo (Bulletin of Saint Petersburg University. Law), 2018, Vol. 9, Issue 4, p. 622.

${ }^{3}$ Ph. Jessup, Transnational Law, New Haven, 1956, pp. 8-9, 108. F. Latty, “Transnational Sports Law", The International Sports Law Journal, 2011, Issues 1-2, p. 34. A. Duval, "Lex Sportiva: a Playground for Transnational Law", European Law Journal, 2013, Vol. 19, Issue 6, p. 825-831.

4 A. Peskov, S. Alekseev (ed.), Sport i protivopravnoye povedenie (Sport and illegal behaviour), Moscow: Prospect, 2017, p. 101-112, 184-185, 190-191, 203-215.

5 M. Stathopoulos, "Sports and European Community Law", in D. Panagiotopoulos (ed.), Proceedings of the $5^{\text {th }}$ IASL Congress, Nafplion 10-12 July, Athens: ELLIN, 1997, p. 23-24. D. Panagiotopoulos (ed.), The Sports Law in the $21^{\text {st }}$ Century. Proceedings of the $1^{\text {st }}$ Pan-Hellenic Congress with the International Participation. Hellenic Center of Research on Sports Law, Athens: ELLIN, 1999, p. 42-44. A. Caiger, S. Gardiner, Professional Sport in the EU: Regulation and Re-regulation. Hague: T.M.C. Asser Press, 2000, p.301-302, cited in D. Panagiotopoulos, Sports Law. Lex Sportiva and Lex Olympica. Theory and Praxis, Athens: Ant. N. Sakkoulas Publishers, 2011, p. 129.

${ }^{6}$ T. Sárközy, "Regulation in Sport as a Borderline Case between State and Law Regulation and Self-Regulation", Acta Juridica Hungarica, 2001, Issues 3-4 (42), p. 173-174. 
The need to clearly define the limits of rule-making powers becomes even more acute when an integration association that unites a number of States in a specific region joins this regulatory process in the domain of professional sports. Integration associations are a collective term for various forms of interstate associations created for the purpose of economic integration. The international free trade area is a rather simple form in which States eliminate tariff and non-tariff restrictions on foreign trade (for example, the European Free Trade Association (EFTA)). In the customs union, States, along with the elimination of tariff and non-tariff restrictions in mutual trade, establish a common tariff policy in relations with third States (the Benelux Union between Belgium, Luxembourg, and the Netherlands could serve as an example). The common market is a more complicated form of economic integration, in which, along with the elimination of tariff and non-tariff restrictions in mutual trade and a common tariff policy in relations with third States, Member States remove all restrictions on the free movement of goods, services, capital, and labour (for example, the European Economic Community). ${ }^{7}$ The Eurasian Economic Union (EAEU) is also aimed at forming a common market between its Member States. The current European Union (EU) is a more advanced form of integration than the common market. The EU pursues integration goals not only in the economic, but also in the political sphere, and has developed a well-structured system of institutions and acquired an exclusive, shared or supporting competence, depending on the range of issues subject to its regulation. Integration processes are evolving in accordance with common patterns, and that is why it is so important for the EAEU to study and take into account the EU's experience in regulating them in general and in regulating sports activities in particular.

The establishment and development of interstate integration associations has an impact on the autonomy of sport, clarifying its content and boundaries. Regional integration brings about the problem of determining the relationship between the law of an integration association and the normative order formed by sports organizations: there appears

7 D. Carreau, P. Juillard, Mezhdunarodnoye ekonomicheskoye pravo (International economic law), 4th ed., translated into Russian, Moscow: International relations, 2002, p. 20. 
a question whether the law of an integration association can interfere with the regulation of those relations that have been traditionally regarded as the "hereditary land of physical culture and sports organizations". ${ }^{8}$ Let us consider how the possibility of regulating certain aspects of professional sports activities is viewed within the framework of two integration associations, such as the European Union, which has been evolving since 1957, and the young Eurasian Economic Union, which was created only in 2014.

\section{AUtONOMY OF SPORT AND ITS INFLUENCE on the Regulation of Relations IN THE FIELD OF SPORTS}

The recognition of sport autonomy has now become a constant feature, and to some extent a paradigm of modern research on the regulation of relations in the field of sports. Such concepts as "autonomy of sport" and "autonomy of sports organizations" have firmly established themselves in the research lexicon. These concepts are used to characterize both the internal regulatory system formed by sports organizations at the international and national levels, and the specifics of the relationship between such organizations and the State.

A distinctive feature of regulating relations in the field of physical culture and sports is the widespread use, along with legal norms, of various rules developed by non-governmental organizations of a noncommercial nature. The principle of autonomy of sport reflects the specifics of sports, namely, the special role of sports organizations that serve as the administrative and regulatory centres. The specificity mentioned above is the capability of certain subjects of physical culture and sports to adopt rules that are binding upon members, participants, founders, or employees of the organizations that elaborated them. It is the absence of a relationship based on a contractual basis or membership between the subject that issued the relevant regulatory act and the subject to

8 T. Melnik, "Gosudarstvennoye regulirovanie i samoregulirovanie v oblsati fizicheskoy kultury i sporta (State regulation and self-regulation in the field of physical culture and sport)", Zhurnal rossiyskogo prava (Journal of Russian Law), 2012, Issue 3, p. 24. 
whom it is addressed, that reflects the specificity of self-regulation in the field of sports. For example, sports federations adopt various rules, regulations, and procedures that specify the status of athletes, coaches, sports clubs, agents, and so forth. The fundamental document of the Olympic movement is the Olympic Charter adopted by the International Olympic Committee. The Charter must be observed by all participants of the Olympic movement, regardless of whether they are members of this organization or not. Thus one can point out to the existence of a self-governing autonomous system in the field of sports, which is not limited only to stand-alone organizations functioning at the international or national level. Therefore, it is necessary to distinguish between legal norms developed by States and self-regulation norms produced by sports organizations.

In this situation, the problem of the correlation between legal and non-legal regulation in the field of sports, and the search for an optimal balance between them, becomes more acute. This problem is becoming one of the key challenges for academics in the sports law area. It should be noted that Polish researchers have made a significant contribution in this field. They study various aspects of the interaction between sports law and norms elaborated by sports organizations, identify possible ways for resolving conflicts between these regulatory systems, ${ }^{9}$ sources, and boundaries of the organizational autonomy of sport. ${ }^{10}$ The autonomy of sport is postulated as one of the most important principles of sports law, which determines the independence of this branch of law. ${ }^{11}$ Rule-making activities of sports organizations are considered in the context of sources of sports law, namely, they are viewed simultaneously as an independent source of regulation and as a factor influencing legal sources. ${ }^{12}$ Polish

${ }^{9}$ K. Romaniec, “Zjawisko niekompatybilności pozaprawnych regulacji sportowych $\mathrm{z}$ regulacjami prawnymi" ("Legal and non-legal regulation in sport: the problem of compliance"), in Andrzej J. Szwarc (ed.), Kompatybilność pozaprawnych regulacji sportowych $z$ regulacjami prawnymi (The ratio of legal and non-legal regulation in sport), Poznań: Wydawnictwo Nauka i Innowacje, 2014, p. 69-111.

${ }^{10}$ M. Biliński, Państwo a sport. Węzłowe zagadnienia prawne (The state and sport. The main legal issues), Kraków, 2011, p. 112-115.

${ }_{11}$ M. Leciak (ed.), Prawo sportowe (Sports Law), Warsaw: C. H. Beck, 2018, p. 16-21.

12 S. Fundowicz, Prawo sportowe (Sports Law), Warsaw: Wolters Kluwer Polska, 2013, p. 21-22. 
academics study the autonomy of sport in the context of legal pluralism. ${ }^{13}$ Separate analysis is given to the autonomy of sport in the context of the European Union law, which is an important and pressing matter for Poland as a member of the European Union. ${ }^{14}$

The Russian science of sports law does not ignore the problems of sport autonomy, either. In this regard, one should pay attention to the studies that focus on this phenomenon in a comparative legal aspect. ${ }^{15}$ Some authors analyze the peculiarities of its manifestation in the Russian sports law. ${ }^{16}$ Although, generally speaking, it should be recognized that Russian researchers find themselves at the initial stage of studying the autonomy of sport as the most important principle of sports law.

Historically, non-governmental organizations were the ones that played a major role in the formation of the modern physical culture and sports system. In such a situation, they were often the pioneers of regulating certain relations in the field of physical culture and sports. In many cases, the State did not show any interest in physical education or sports activities. It is no accident that in the research papers devoted to developing special legislation on physical culture and sports, many academics often use such terms as "interference" and "intervention" to designate the participation of the State in the regulation of relations in this field. ${ }^{17}$ Thus, de facto attention is drawn to the fact that state regulation fell behind with regulation on the part of other social structures, and the inclusion of the state in the process of regulating physical culture

${ }^{13}$ H. Radke, "Prawo międznarodowych federacji sportowych a prawo krajowe" ("Law of inernational sports federations and national law"), in D. Bunikowski, K. Dobrzeniecki (eds.), Pluralizm prawny (Legal Pluralism), Toruń, 2009, p. 333-372.

${ }^{14}$ B. Rischka-Słowik, Konstytucja sportu w Unii Europejskiej (Constitution of sport in the European Union), Warsaw: C. H. Beck, 2014.

15 A. Ponkina, Avtonomnost sporta. Teoretiko-prawowoye issledowanie. (Autonomy of sport. Legal study), Moscow, 2013.

${ }^{16}$ A. Koshel, "Gosudarstvennoye regulirovanie i samoregulirovanie v oblsati professionalnogo sporta ("State regulation and self-regulation in the field of professional sport"), Zhurnal rossiyskogo prava (Journal of Russian Law), 2012, Issue 6. D. Machnik, "Publichno-chastnoye sotrudnichestvo v oblsati fizicheskoy kultury i sporta" ("The publicstate cooperation in the field of physical culture and sport"), Zakonodatelstvo i ekonomika (Legislation and Economics), 2016, Issue 11. Melnik, supra note 8, p. 24.

17 Radke, supra note 13, p. 360. 
and sports inevitably led to a revision of rule-making competences between them.

At present, there is a need to determine potential social regulators of physical culture and sports. For instance, in Europe there is an active discussion on the need to take into account the specifics of sports and the autonomy of sport. Therewith the concept of autonomy of sport, based on the recognition of significant rights of non-governmental and not-for-profit organizations, including rights to adopt their own rules, is reflected in many official acts.

Academics note that since the end of the 1980s, the official documents of the Council of Europe and the European Union have been consistently supplemented by provisions on the autonomy of sports organizations and on the autonomy of sport. ${ }^{18}$ The autonomy or independence of sport in general, and of voluntary sports organizations in particular, is declared to be a characteristic feature of the European sports model. Ultimately, this model should be focused on ensuring the openness and democracy of sports. For instance, Resolution 1602 (2008), adopted by the Parliamentary Assembly of the Council of Europe in January 2008, emphasizes that "the independent nature of sport and sports bodies must be supported and protected, and their autonomy to organize the sport for which they are responsible should be recognized".${ }^{19}$ Autonomy in sport was one of the main points on the agenda of the 11th Conference of the European Ministers responsible for the development of sport, which was held in Athens in December, 2008. The Recommendations formulated in the Resolution CM/ $\operatorname{Rec}(2011) 3$ of the Committee of Ministers of the Council of Europe are of great importance in the context of the present subject matter because they contain the characteristic features of the autonomy of sport. In particular, the ability of non-governmental non-profit sports organizations to freely establish, amend, and interpret the "rules of

18 J-L. Chappelet, Autonomy of sport in Europe, Strasbourg, 2010, p. 16.

${ }^{19}$ Resolution 1602 (2008) 1 "The need to preserve the European sports model" adopted on 24 January 2008 by the Parliamentary Assembly of the Council of Europe, available at: https://www.coe.int/T/r/Parliamentary_Assembly/[Russian_documents]/[2008]/ [Jan2008]/Res1602_rus.asp\#P4_75 [last accessed 15.6.2020]. 
the game" for their sport is emphasized as an integral element of such autonomy, without undue political or economic influence. ${ }^{20}$

Among the official acts of the European Union, particular attention should be paid to the Lisbon Treaty, which amended Article 149 of the Treaty on the Functioning of the European Union with a view to recognizing the specifics of sports based on voluntary self-organization. ${ }^{21}$ Thus, the European Union has acquired the authority to implement a coordinated policy in the field of sport. Previously, this was done sporadically and had no legal basis in the constituent documents. The logical consequence of the emergence of a new type of competence presented itself in a coordinated EU policy in the field of sport. Starting from 2011, the EU Work Plan for Sport was adopted for the four years to come. ${ }^{22}$ The first EU four-year Work Plan for Sport was adopted in 2011 by the EU Council Resolution 2011/C 162/01 for the period 2011-2014. The second EU Work Plan for Sport for 2014-2017 was approved in 2014 by the EU Council Resolution 2014/C 183/03. Now the third EU Work Plan for Sport, approved for the period 2017-2020 by the Resolution 9639/17 of 24.5.2017 of the EU Council and representatives of the governments of the EU Member States, is currently in force. ${ }^{23}$ Each of these Work Plans outlines the Union's priority areas in the field of sport, formulates planned results of activities, and sets the deadlines and responsible authorities.

In the third EU Work Plan for Sport a specific reference is made to the autonomy of sport, which is called "specificity of sport" in paragraph 12 of this document, where three priority areas of EU activities in the

${ }^{20}$ Recommendation CM/Rec (2011) 3 of the Committee of Ministers to Member States on the principle of autonomy of sport in Europe, available at: https:/ / search.coe. int/cm/Pages/result_details.aspx?ObjectID=09000016805b4d00 [last accessed 15.6.2020].

${ }^{21}$ Treaty of Lisbon amending the Treaty on European Union and the Treaty establishing the European Community, available at: https://eur-lex.europa.eu/legalcontent/EN/TXT/?uri=CELEX\%3A12007L\%2FTXT [last accessed 15.6.2020].

22 See in more detail, L. Zakharova, K. Bekyashev (ed.), International Sports Law: textbook for Bachelor students, Moscow: Prospekt, 2018, p. 140-141.

${ }^{23}$ Resolution of the Council and of the Representatives of the Governments of the Member States, meeting within the Council, on the European Union Work Plan for Sport (1.7.2017 - 31.12.2020). Council of the EU Resolution 9639/17, 23.5.2017, available at: http:/ / data.consilium.europa.eu/doc/document/ST-9639-2017-INIT/en/pdf [last accessed 5.6.2020]. 
field of sport are identified. Annex 1 explains that a new EU legislative act in relation to sport and sport organizations will be elaborated under the coordination of the European Commission. Sport is developing dynamically within the EU, and this is likely to result in further regulation of sports relations within the Union, as prescribed by the EU Work Plan for Sport for 2017-2020 that envisages a clearer division of rule-making powers between the EU and sports organizations.

In the academic literature it has been suggested that European sports law as an integral part of the EU law is being formed. It is aimed at regulating top and amateur sports where EU citizens are involved, ${ }^{24}$ and the combination of state regulation and non-state regulation in sports can be seen among its special principles. ${ }^{25}$

The development of the European Union law has had a significant impact on the scope of the rule-making rights of non-governmental nonprofit organizations in the field of sports. ${ }^{26}$ So, in practice there arose a question of whether the law of the European Union can infringe on the regulation of relations that have traditionally been considered as the competence of sports organizations. Some judgments rendered by the Court of Justice of the European Union (e.g., in the Bosman, Simutenkov, or Meca-Medina cases), are a cause of anxiety for the European sports federations, since the CJEU recognized in them the applicability of the EU law and interstate agreements to regulating relations that had been previously viewed as the object of self-regulation by non-state sports organizations - in their view, these judgments significantly limit the independence and autonomy of sport and do not take into account the

${ }^{24}$ S. Weatherill, European Sports Law, Collected Papers, 2nd ed., The Hague: T.M.C. Asser Press, 2014. J. Fox, “European Union and Sport”, Europa - the Polish Institute of International Relations, Vol. 3, Issue 3 (8), 2003.

25 A. Iglin, "Rol' globalizatsii v razvitii mezhdunarodnogo i evropeyskogo sportivnogo prava" ("The Role of Globalization in the Development of International and European Sports Law"), in Rossiyskiy ezhegodnik mezhdunarodnogo prava 2014 (2014 Russian Yearbook of International Law), Saint Petersburg: “Russia-Neva” Publishing house, 2015, p. 260-261.

${ }^{26}$ R. Parrish, C.B. Carcia, R. Siekmann, The Lisbon Treaty and EU Sport Policy, Brussels, 2010. M. Tonk, T. Nagy-Méhész, A.V. Voicu, "«Autonomy» of Sport Policy and Sport Activities in the European Union: Connections between Human Rights and Sports", Acta Universitatis Sapientia. European and Regional Studies, 2010, Issue 1 (Vol. 1), p. 103-120. 
specifics of sports. ${ }^{27}$ It is rightly recognized in the academic literature that the autonomy of sport is largely linked to the right to association. ${ }^{28}$ The independence of sports non-governmental non-profit organizations in determining their internal structure, in setting and achieving their statutory goals, and in developing their charters is undoubtedly a manifestation of the freedom of association, and these organizations themselves present a possible form of implementing the right to association.

The permissible limit of state interference in the activities of sports federations is also determined by international legal standards concerning the right to association. In this regard, the active work of the Council of Europe is worth mentioning. The Council of Europe pays close attention to the enforcement of the right to association as an independent form of self-regulation within society through various mechanisms, namely the political and legal (Parliamentary Assembly), jurisdictional (European Court of Human Rights) and expert bodies (European Commission for Democracy through Law).

In addition, in relation to sports federations, the Council of Europe has developed additional approaches with the use of the soft law instruments to ensure the independence of public associations in the field of sports and prevent any manifestations of etatism in this respect. This refers to the concept of sport autonomy whose basic provisions are laid down in the Recommendation of the Committee of Ministers of the Council of Europe CM/Rec (2011) 3. In particular, it provides an opportunity for non-governmental non-profit sports organizations to freely establish the rules of their sport, manage their own affairs, obtain adequate funds from public or other sources without disproportionate obligations, use them to achieve their statutory objectives, and carry out their activities without severe external constraints.

For the purposes of determining their relationship with the State, the constitutionally significant characteristics of public sports organizations should include, first of all, their self-determination and independence from the State. Public associations are established freely, without the

27 G. Infantino, Meca-Medina: a step backwards for the European Sports Model and the Specificity of Sport?, available at: http://www.uefa.com/MultimediaFiles/Download/ uefa/KeyTopics/480391_DOWNLOAD.pdf [last accessed 14.6.2020].

${ }^{28}$ Leciak (ed.), Prawo, supra note 11, p. 17. 
participation of state authorities, and they serve as an organizational and legal means of meeting diverse social needs.

This understanding dictates special requirements for a state policy in relation to public associations in the sport sector. To a great extent the need to specify the characteristics of the legal status of public sports organizations determines the content of legislation on physical culture and sports and forms the subject matter of such legislation. The Polish and Russian experience in this field can be cited as an example.

For instance, the 2010 Polish law "On Sports" focuses on the legal status of sports unions, the purpose of which is to organize and conduct competitions in respective sports discipline. ${ }^{29}$ The 2007 Russian Federal Law "On Physical Culture and Sport in the Russian Federation" № 329-FZ recognizes the central role of sports federations in the system of physical culture and sports. These federations serve as a form of social self-organization for the development of certain sports. ${ }^{30}$ The following types of sports federation are legally recognized: local sports federations functioning on the territory of municipalities, regional sports federations whose activities are limited to the territory of a subject of the Russian Federation, and all-Russian sports federations.

Both sports unions in Poland and sports federations in Russia are established on the basis of the right to association. They are accordingly subject to the safeguards provided by the legislation on public associations (in Poland it is the Law "On Associations" of 7.4.1989, in the Russian Federation it is the Federal Law "On Public Associations" No.82-FZ of 19.5.1995).

At the same time, the legal status of sports unions and sports federations has its peculiarities. Specific mechanisms for the interaction of these organizations with the State are established respectively. In particular, the Polish legislator provides that a sports union can be established with the permission of the minister responsible for the development of physical culture. Under the Russian legislation, in order to apply for the status of a sports federation it is necessary to obtain state

29 The Law “On Associations" of 7.4.1989, available at: http://isap.sejm.gov.pl/ isap.nsf/download.xsp/WDU20101270857/U/D20100857Lj.pdf [last accessed 17.6.2020].

30 The Federal Law "On Public Associations" No.82-FZ of 19.5.1995, available at: http:/ / pravo.gov.ru [last accessed 17.6.2020]. 
accreditation, which is issued for 4 years. For regional federations, state accreditation is performed by the state authorities of the subjects of the Russian Federation, in the case of the all-Russian sports federations - by the federal ministry responsible for the state policy in the field of physical culture and sports.

Polish sports unions are subject to special supervision by the minister authorizing permits for the establishment of sports unions. In Russia, there is no separate supervision on the activities of sports federations, and the Ministry of Sports, which is responsible for the development of sports, does not have the appropriate powers. In the framework of the state accreditation procedure, it has only the right to assess the compliance of a sports federation with the requirements for obtaining this accreditation. As far as the supervision is concerned, it is carried out by the Ministry of Justice as a part of the overall supervision over all non-governmental non-profit organizations, including sports federations.

We are of the opinion that establishing a special model of relations between the State and public sports organizations in the national legislation, including special licensing, control, and reporting mechanisms, is largely due to the specific role that public sports organizations play in the system of physical culture and sports. Being responsible for the development of a particular sport, they have special rights that are not enjoyed by other public structures, more specifically the right to form their own regulatory framework through the elaboration, adoption, and implementation of the rules that are used in a particular kind of sports. It should be noted that these rules are mandatory, not only for members of public associations, but also for other persons, such as athletes, coaches, and sports clubs that do not have the status of members of the relevant public associations. For instance, under the Polish law "On Sports", a sports union is entitled to approve sporting, organizational, and disciplinary rules for competitions, except for anti-doping rules.

In the Russian Federation, it is recognized that along with state regulation self-regulation is carried out in the field of physical culture and sports. Self-regulation on the part of the all-Russian sports federations has the following manifestations.

First, they are entitled to approve norms that establish rights and obligations, including sports sanctions, for those subjects of physical culture and sports who recognize such norms. At the same time, although 
the legislator identifies the subjects to whom the regulatory requirements of all-Russian sports federations can be addressed, it should be recognized that in fact this refers to an indefinite range of persons, since the list of subjects of physical culture and sports is extremely broad (in particular, they include physical culture and sports organizations, citizens engaged in physical culture and sports, etc.). In contrast to laws and regulations, voluntary consent is the basis for a person to recognize the regulatory force of normative acts of all-Russian sports federations. In the research papers, such voluntary consent is considered as a so-called "contract for participation" in sports events organized and conducted by sports organizations. ${ }^{31}$

Even though the Federal Law "On Physical Culture and Sport in the Russian Federation" emphasizes the voluntary nature of the rules of sports federations that establish the rights and obligations of subjects of physical culture and sport, it should be noted that there is a certain conventionality of such voluntariness. The fact is that the modern physical training and sports movement is based largely on centralization principles. From the institutional perspective, the organizational structure of such movements resembles a pyramid, whose basis is formed by sports clubs, athletes, and coaches. The next tier is occupied by national federations, national Olympic committees, and on top of it there is an international nonprofit organization that manages, for example, a certain sport discipline. Decisions, rules, and norms of a higher organization are mandatory for lower-level subjects, and a failure to comply with them leads to sanctions, including a ban on participation in sports competitions, which is "capital punishment", since it entails an expulsion from the system of physical culture and sports.

Second, the Federal Law "On Physical Culture and Sport in the Russian Federation" provides for other opportunities of self-regulation by all-Russian sports federations, in addition to the general recognition of rules adopted by those public associations that establish the rights and obligations of the subjects of physical culture and sport. This refers to the right of these public associations to impose restrictions on the

${ }^{31}$ S. Thorp, A. Leadercramer, "Self-regulation of sport: arguments for and against", Worlds Sport Law Report, 2010, Issue 8, p. 7. 
participation in the all-Russian official sports competitions in the relevant sports for athletes who are not eligible to play for sports teams of the Russian Federation in accordance with the rules of international sports organizations that conduct relevant international competitions, and taking into account the restrictions on participation in competitions of such persons established by the Ministry responsible for the development of physical culture and sports. This means that all-Russian sports federations can impose restrictions on the participation of foreigners and stateless persons in the relevant sports competitions.

The ability to create a specific regulatory framework that does not coincide with the legislation is one of the most important manifestations of autonomy of sport. ${ }^{32}$ At the same time, as is emphasized in the academic literature, the right of sports organizations to adopt their rules is not absolute and is subject to state control. ${ }^{33}$

Thus, paradoxically, the autonomy of sport entails the establishment of additional licensing and supervisory mechanisms for public sports organizations at the national level, as the Polish and Russian experience shows. Recently one more state in Europe has demonstrated a somewhat controversial approach in this respect - if not a willingness to ignore the autonomy of the sport principle completely, but the intent to put it somewhat aside. German courts of general jurisdiction have been quite actively involved in the settlement of several high-profile sports disputes. Considering the appeal of the famous German speed skater Claudia Pechstein against the decision of the district court in Munich, the Higher Court of Appeal (Land Court) concluded in its decision of 15 January, 2015 that the decision that had been rendered by the Court of Arbitration for Sport in Lausanne (CAS) was not enforceable in Germany. In the opinion of the Land Court, the International Skating Union occupies a dominant position in the organization of sports competitions in speed skating. Consequently, the ISU is subject to the provisions of the German competition law, which prohibits taking advantage of such a position, i.e. requiring an athlete to accept an arbitration clause to resolve a dispute in the CAS. However, on 7 June, 2016 the German Federal Tribunal

32 Leciak (ed.), Prawo, supra note 11, p. 19.

${ }^{33}$ Radke, supra note 13, p. 360. 
overturned the decision of the appellate instance, emphasizing that the acceptance by athletes of the arbitration clause set out in the ISU Charter in favour of the CAS does not constitute an abuse of a dominant position in the sense of German competition law and that the CAS meets the criteria of a "genuine arbitration tribunal". ${ }^{34}$

The process of considering the Pechstein case in the German courts drew great attention from Russian sports lawyers. So, S. Yurlov, commenting on the decision of the Higher Court of Appeal in the Pechstein case, noted that in Russia it would be difficult to apply the Law "On the Protection of Competition" of 26.7.2006, No. 135-FZ (as amended on 18.7.2019), because Russian sports federations are created in the form of public non-profit organizations - hence, a sport federation cannot be recognized as an entity occupying a dominant position, and he urged making the necessary changes to para. 5, article 4 of the Law "On the Protection of Competition", providing a greater detail to the concept of "an economic entity". ${ }^{35}$ Reflecting on the decision of the German Federal Tribunal in the Pechstein case N. Peshin summarized it as follows, "Today we have international sports federations who dominate, but do not abuse their dominance in sport, and an independent and impartial international court of arbitration (CAS), whose right to hear cases of athletes without their consent was confirmed by the national supreme courts in some European states," however, he expressed his doubts about the stability of the current system. ${ }^{36} \mathrm{~S}$. Weatherill, a British academic who writes extensively on various aspects of European law including EU sports law, suggests that

${ }^{34}$ Pechstein/International Skating Union. KZR 6/15, 7.6.2016, German Federal Tribunal, available at: http:/ /juris.bundesgerichtshof.de/cgi-bin/rechtsprechung/document.py?G ericht $=$ bgh \&Art=pm\&sid $=54852$ b5380819f317e13cc17aead74a6\&nr=75021\&linked $=$ urt $\& B 1$ ank=1\&file=dokument.pdf [last accessed 10.6.2020]. Court of Arbitration for Sport (CAS). Press release of 7.6.2016, available at: https:/ / www.tas-cas.org/fileadmin/user_upload/ Media_Release_Pechstein_07.06.16_English_.pdf [last accessed 10.6.2020].

35 S. Yurlov, Sportivnye spory i ih razreshenie: teoriya i praktika (Sports disputes and their settlement: theory and practice), Moscow: Infotropic Media, 2015, p. 113-116.

${ }^{36}$ N. Peshin, "Problemy antidopingovogo obespecheniya v kontekste resheniy Sportivnogo arbitrazhnogo suda (Lozanna)" ("Problems of anti-doping support in the context of the decisions of the Court of Arbitration for Sport (Lausanne)"), Bulletin of the Russian International Olympic University, 2019, Issue 2 (31), p. 57. 
"it is competition policy that will be the major battleground in the future elaboration of the application of EC law to sport" ${ }^{37}$

Drawing conclusions in this part, one should note the existence of two mutually exclusive trends: on the one hand, national legislators take into account the regulatory systems established and maintained by various sports organizations. The pluralism of regulatory instruments reflects the key feature of sports. On the other hand, state authorities are sometimes tempted to intervene in the realm of sports, trying to protect public interests according to their understanding. The most important task for the State and sports authorities nowadays is to find mechanisms for coordinating two regulatory levels - legal and non-legal.

Moreover, the problem of the autonomy of sport takes on a new dimension in the intensification of integration processes, since in addition to the domestic national law, the law of integration associations comes into play, and in its turn, it claims supremacy over the rule-making activities of sports organizations. Thus, in addition to the traditional dichotomy "national law - rules of sports federations or sports unions", there appears an additional field of tension and potential conflicts caused by the search for an optimal balance between the law of integration associations and the autonomy of sports organizations. In this process a significant role can be played by the judicial institutions of integration associations.

\section{The CJEU JuRisprudence on Regulating PROFESSIONAL SPORTS}

\section{The Recognition of the Principle OF THE AUTONOMY OF SPORT}

The Court of Justice of the European Union (the Court of Justice of the European Communities (CJEC) from 1958 until the entry into force of the Lisbon Treaty in 2009) contributes to a uniform understanding of the

${ }^{37}$ S. Weatherill, "Sports under EC Competition Law and US Antitrust Law", European Sports Law. Collected Papers. Second edition, Asser International Sports Law Series, The Hague: T.M.C. Asser Press, 2014, p. 157. 
norms enshrined in the EU law. The CJEU, when interpreting the rules governing professional sports, differentiates between issues in which the sports movement retains its autonomy (for example, the preparation and holding of the world championships in an Olympic sport), and the labour (economic) activities of athletes, which are subject to the Union law.

This distinction was clearly made in the CJEC judgment in the case of Walrave and Koch v. International Cycling Union, the Netherlands Cycling Association and the Spanish Cycling Association. ${ }^{38}$ The applicants Bruno Walrave and Longinus Koch, subjects of the Kingdom of the Netherlands, were motorcycle leaders in bicycle races in which cyclists followed motorcycle racers. In 1970 the International Cycling Union (ICU) introduced new rules to be used during the world middle-distance cycling championship in 1973. One of them required that cyclists and motorcycle racers should have the same citizenship, since the championship was a competition between national teams. Walrave and Koch played for the national teams of Belgium and Germany, the innovation infringed on their rights, motorcycle racers considered the new requirement discriminatory, and filed a lawsuit against the ICU, the Spanish Cycling Association and the Cycling Association of the Netherlands. The case was filed in the Court of Utrecht (the Netherlands), which on 15.5.1974 referred to the CJEC the question of whether the ICU new rules complied with the 1957 Treaty Establishing the European Economic Community (Treaty of Rome) and the European Community Regulation of 15.10.1968 No. 1612/ 68 “ On the free movement of workers within the Community".

In this case, the CJEC stated that sports activities fall under the Community law only if they are economic activities within the meaning of article 2 of the Treaty of Rome, in which the promotion of "the harmonious development of economic activities" is stated as one of the objectives of the Community. ${ }^{39}$ When sports activities have the nature of labour

${ }^{38}$ Bruno Walrave, Longinus Koch and Association Union Cycliste Internationale, Koninklijke Nederlandsche Wielren Unie, Federacion Española Ciclismo. Case 36/74, Judgment of 12.12.1974, Court of Justice of the European Communities, available at: https:/ / eur-lex.europa.eu/ legal-content/EN/TXT/PDF/?uri=CELEX:61974CJ0036\&qid=1583768927605\&from=EN [last accessed 10.6.2020].

39 Treaty establishing the European Economic Community, 14 April 1957, available at: http:// docs.cntd.ru/document/901771692 [last accessed 10.6.2020]. 
(economic) activities or paid services - and Walrave and Koch v. ICU was the first case of this kind brought before the $\mathrm{CJEC}^{40}$ - they are regulated accordingly by articles $48-51$ or 59-66 of the Treaty of Rome (para 4-5 of the reasoning part of the decision) ${ }^{41}$ However, the prohibition of ethnic discrimination is enshrined in three articles of the Treaty of Rome referred to by the Court such as article 7 (prohibition of all discrimination on grounds of nationality), 48 (cancellation of any ethnic discrimination against workers of Member States as regards employment, remuneration, and other conditions of work and employment), 59 (progressive abolition of restrictions on the free provision of services in the Community during the transitional period), does not affect the way of formation of sports teams, in particular national teams, the formation of which is a question of a purely sporting interest and has nothing to do with economic activities (para. 2 of the operative part of the decision).

Having interpreted the articles of the Treaty of Rome mentioned above, the CJEC left it to the Court of Utrecht to make a final decision on the applicability of the Community law. However, in the end Walrave and Koch refused to continue the proceedings in the Court of Utrecht, because the ICU threatened to exclude motorcycle racing completely from the programme of the World Cycling Championship.

\section{ISSUES OF LABOUR (ECONOMIC) ACTIVITIES of Professional Athletes in the Practice OF THE CJEU}

The CJEU has repeatedly spoken out on the issues of free movement of workers, including athletes, as well as on the issue of the compliance

${ }^{40}$ M. Gros, P.-Y. Verkindt, "L'autonomie du droit du sport. Fiction ou réalité?", ("The autonomy of sports law: fiction or reality?"), L'actualité juridique droit administratif (Legal news in administrative law), December 1985, p. 707.

${ }^{41}$ Articles 48-51 of the Treaty of Rome deal with the free movement of workers within the Community and their rights on the territory of Member States. Articles 59-66 of the Treaty of Rome define "services" as (a) activities of an industrial nature; b) activities of a commercial nature; c) activities of artisans; d) activities of persons of free professions and proclaim the free provision of services in the Community. 
of corporate norms of sports organizations with the EU competition law. ${ }^{42}$

In resolving two cases, which will be discussed below, the Court of Justice of the European Communities considered that sports activities under certain conditions constitute labour (economic) activities and therefore fall under the regulation of the Union within the meaning of article 2 of the 1957 Treaty of Rome (creation of a single internal market). The principle of the free movement of persons (freedom of movement of persons) is one of the four main principles (freedoms) of the EU internal market, which can be derived from article 26 of the Treaty on the Functioning of the European Union (TFEU) in the version of the Lisbon Treaty of 2007): this is the free movement of goods, persons, services and capitals. ${ }^{43}$

Article 45 of the TFEU lists in a detailed way the rights that ensure the free movement of workers:

(a) to accept offers of employment actually made;

(b) to move freely within the territory of Member States for this purpose;

(c) to stay in a Member State for the purpose of employment in accordance with the provisions governing the employment of nationals of that State laid down by law, regulation or administrative action;

(d) to remain in the territory of a Member State after having been employed in that State, subject to conditions which shall be embodied in regulations to be drawn up by the Commission.

Article 45 of the TFEU allows restrictions on the freedom of movement for workers only in two cases:

1) for reasons of public policy, public security and public health (para. 3 of part 1 of article 45 of the TFEU);

${ }^{42}$ See an overview of the CJEU decisions on these issues (rendered in 1974-2010) in V. Blazheev, V. Bayramov et al., D. Rogachev (ed.), Sportivnoye pravo Rossii (Russian Sports Law): textbook for Master students, Moscow: Prospect, 2016, p. 605-613.

${ }^{43}$ Consolidated versions of the Treaty on European Union and the Treaty on the Functioning of the European Union, 13.12.2007, available at: https://eur-lex.europa. eu/legal-content/EN/TXT/?uri=uriserv:OJ.C_.2016.202.01.0001.01.ENG\&toc=OJ:C: 2016:202:FULL [last accessed 10.6.2020]. 
2) when working in the public administration (part 2 of article 45 of the TFEU), which means "direct and special participation in the exercise of public power" (for example, working as a police officer, military officer, judge, etc..$^{44}$

A landmark decision was rendered in the case Belgian Football Union v. Jean-Marc Bosman, Royal club of Liege v. Jean-Marc Bosman, Union of European Football Associations (hereinafter-UEFA) v. Jean-Marc Bosman of 15.12.1995. ${ }^{45}$ In October 1993 the Court of Appeal of Liege (Belgium) appealed to the CJEC with a preliminary request concerning the interpretation of articles $48,85,86$ of the Treaty of Rome. ${ }^{46}$ Article 48 of the Treaty of Rome is particularly important in the context of the topic under consideration: it defines the content of the principle of free movement of workers and abolishes any discrimination on the basis of nationality against workers of Member States in respect of employment, remuneration, and other conditions of work and employment.

The Court of Appeal of Liege asked the CJEC whether articles 48, 85 and 86 of the Treaty of Rome of 25.3.1957 should be interpreted as:

1) prohibiting a football club from requesting and receiving monetary payments when one of its players, whose contract has already expired, enters into a contractual relationship with a new club;

2) prohibiting national and international sports associations or federations from including in their respective regulations provisions restricting the access of foreign players from the European community to the competitions they organize (para. 49 of the Court of Justice of the European Communities judgment in Bosman case).

In its judgment of 15.12.1995 the CJEC did not accept the argument that sport was not regulated in Community law and confirmed its position

${ }^{44}$ S. Kashkin (ed.), Pravo Evropeyskogo Soyuza (European Union Law): textbook for Bachelor students, Moscow: Prospect, 2018, p. 177.

45 Union Royale belge des Sociétés des Football Association ASBL v. Jean-Marc Bosman, Royal Club Liègeois SA v. Jean-Marc Bosman and Others and Union des Associations Européennes de Football (UEFA) v. Jean-Marc Bosman, European Court of Justice, Case C-415/93, Judgment of 15.12.1995, available at: http:/ / eur-lex.europa.eu/legal-content/EN/TXT/PDF/?uri $=$ CELEX:61993CJ0415\&rid $=1$ [last accessed 10.6.2020].

46 Treaty establishing the European Economic Community, 14 April 1957, available at: http:/ / docs.cntd.ru/document/ 901771692 [last accessed 10.6.2020]. 
that sports activities were subject to Community law to the extent that they constituted economic activities (para. 73). Although the Court agreed with the thesis that it was difficult to distinguish between economic and sporting aspects in football (para.76), it pointed out that the existing autonomy of the activities of sports organizations (para.79 of the decision) was not absolute - it was limited by the Treaty of Rome (para.81). The CJEC held that article 48 of the Treaty of Rome prevented both the application by sports clubs of the rules of sports associations that established the procedure for making transfer payments (para.114) and the application of the rules according to which the sports associations themselves could only field a limited number of foreign players - citizens of the Member States (para. 137). As a result of resolving this dispute, a precedent emerged that established the principle of freedom of movement for workers in relation to professional football players and led to the changes in the transfer rules, in particular, quotas for the players from the European Community States were cancelled. ${ }^{47}$

More recently the Court has repeatedly ruled on issues related to the free movement of professional athletes. In the case Igor Simutenkov v. Ministry of Education and Culture, Royal Spanish Football Federation, rendered in 2005, which is of particular interest to professional athletes who are citizens of Russia, the Court pointed to the similarity of the wording of para.1 of article 38 of the Europe Agreement establishing an association between the European Communities and their Member States and the Slovak Republic of 4 October, 1993 and para.1 of article 23 of the Agreement on partnership and cooperation between the European Communities and their Member States, of one part, and the Russian Federation, of the other part, of 24 June 1994 (para.34) and repealed the discriminatory provisions in respect of working conditions, remuneration, or dismissal in relation to Russian athletes, which helped to strengthen the principle of equality in the implementation of the right to decent working conditions. In its decision, the Court indicated that section 1 of

${ }^{47}$ For more information, see L. Zakharova, "Vliyaniye Konsultativnogo zaklyucheniya Suda EAES ot 7 dekabrya 2018 goda na osuschestvleniye trudovoy deyatelnosti professionalnyh sportsmenov" ("Impact of the Advisory opinion of the EAEU Court of 7.12.2018 on the employment of professional athletes"), Mezhdunarodnoye pravosudiye (International Justice), 2020, Issue 1 (33), p. 100-102. 
article 23 of the 1994 Agreement on partnership and cooperation should be interpreted as preventing a sport federation from the application in respect of a professional Russian athlete legally employed by a club established in any Member State of the corporate rules under which sport clubs would be allowed to field only a limited number of players from third countries, which are not parties to the agreement on the European Economic Area, in national competitions (para. 41). ${ }^{48}$ The Agreement on the European Economic Area of 2.5.1992 extended the four freedoms of movement of goods, persons, services, and capital to the Member States of the European Free Trade Association (EFTA), ${ }^{49}$ to which the Russian Federation is not a party. The same goal was pursued by the bilateral association agreements that were concluded after 1992 between the European Union and the Eastern European States, as well as the Agreement on partnership and cooperation that was concluded between the EU and the Russian Federation.

The academic literature notes that decisions in cases related to the status of foreign players, such as the Bosman and Simutenkov cases, clearly demonstrate the special role of the CJEU in ensuring uniformity and harmonization of professional sports regulation based on the principles of European Union law. ${ }^{50}$

Thus, in a number of its decisions the CJEU has demonstrated the following approach: with the two exceptions explicitly mentioned in article 45 of the TFEU, other restrictions on the freedom of movement are inadmissible, not only in respect of workers from EU countries, but also in respect of citizens of EFTA Member States and those States with which the EU has an agreement establishing an association or an agreement on partnership and cooperation.

Now that the CJEU has resolved more than thirty cases in the field of sports, it can be stated that the decisions rendered by the Court encouraged

${ }^{48}$ Igor Simutenkov v. Ministerio de Educación y Cultura, Real Federación Española de Fútbol, Case C-265/03, Judgment of the CJEC (Grand Chamber) of 12.04.2005, available at: http:/ / eur-lex.europa.eu/legal-content/EN/TXT/PDF/?uri=CELEX:62003CJ0265\& rid=1 [last accessed 10.6.2020].

49 Agreement on the European Economic Area, 2.5.1992, available at: https:/ / base. garant.ru/2564517/ [last accessed 10.6.2020].

${ }^{50}$ Romaniec, supra note 8, p. 83-84. 
sports organizations operating on the territory of the European Union Member States to "adapt to the Rome Treaty and the Union legislation in its entirety". ${ }^{51}$ Sport is developing dynamically in the EU, and this is likely to lead to further regulation of sports relations within the Union, as prescribed by the EU Work Plan for sport for 2017-2020 (at a minimum, a clearer separation of rule-making powers between the EU and sports organizations is expected).

\section{The EAEU JURISPRUdence On REgUlating PROFESSIONAL SPORTS}

The Eurasian Economic Union (EAEU) is an integration association that unites five states situated in Europe and Asia, namely Armenia, Belarus, Kazakhstan, Kyrgyzstan and Russia. The EAEU court was established in accordance with the Treaty on the Eurasian Economic Union of 29.5.2014 and started its work on 1.1.2015. Thus, unlike the EU Court of Justice, it still finds itself at the beginning of the road leading to the formation of a unified legal order within the framework of an integration association. There is no separate act yet that could regulate relations in the field of sports at the level of the EAEU.

However, on 7.12.2018 the EAEU Court issued the Advisory opinion "On the clarification of the application of paragraph 2 of article 97 of the EAEU Treaty in respect of the employment of professional athletes who are citizens of EAEU Member States and the possibility of introducing into the national legislation of quantitative restrictions this category of people at work" where the Court first spoke on the issue of freedom of movement of labour resources within the Union and on its possible limitations by the Member States..$^{52}$ In the Advisory opinion the Court

${ }^{51}$ I. Nosyreva, "Regulirovaniye sporta v stranah ES (analiz praktiki Suda ES)” (“Sport regulation in the EU countries (analysis of the CJEU practice)"), Sport: ekonomika, pravo, upravleniye (Sport: Economics, Law, Management), Issue 4, 2019, p. 32-33.

${ }^{52}$ Advisory opinion "On the clarification of application of paragraph 2 of article 97 of the EAEU Treaty in respect of the employment of professional athletes who are citizens of EAEU Member States and the possibility of the introducing into the national legislation of quantitative restrictions to this category of people at work", 7.12.2018, 
pointed out that article 4 of the Treaty on the EEU proclaims the formation of a single market for goods, services, capital, and labour resources within the Union as one of the main goals of the EAEU, and recalled that article 2 of the Treaty defines the common (single) market as "a set of economic relations within the Union, under which the freedom of movement of goods, services, capital, and labour is ensured". In other words, the free movement for workers is an integral element of the single internal market mechanism.

Within the framework of the European Economic Commission (EEC) request, three key issues were raised before the EAEU Court. First, it was necessary to find out whether professional athletes should be viewed as workers. Substantiating the answer to it, the Court stated that "regardless of the position that professional athletes have in accordance with the legislation of each of the Member States of the Union, they are workers in the sense of the Union law, they have the same status within the Union and enjoy the rights and legitimate interests established by the Treaty" (para 3 part III, "Findings of the Court").

Secondly, the Commission asked for clarification as to whether article 97 of the Treaty applies to the restrictions imposed by public sports organizations (associations). The EAEU Court again answered in the affirmative, "the provisions of paragraphs 1 and 2 of article 97 of the Treaty do not allow the introduction and use of any limitations of labour activities of professional athletes who are workers of the Member States at the level of national legislation and regulations, and also prohibit the organizations of physical culture and sports who are employers of professional athletes to apply such limitations no matter whether these limitations are established by the laws or regulations or imposed by the local acts of the organization concerned" (para 5 part III, "Findings of the Court").

In similar circumstances, the Court of Justice of the European Communities in its judgment in the Bosman case stated quite categorically that "the abolition as between Member States of obstacles to freedom

Court of the Eurasian Economic Union, available at: http:/ /www.consultant.ru/cons/ cgi $/$ online.cgi? req=doc\&base $=$ LAW $\& \mathrm{n}=313086 \&$ fld $=134 \& d s t=1000000001,0 \& \mathrm{rnd}=$ $0.5994912331479239 \# 06923909961619146$ [last accessed 10.6.2020]. 
of movement for persons and to freedom to provide services would be compromised if the abolition of State barriers could be neutralized by obstacles resulting from the exercise of their legal autonomy by associations or organizations not governed by public law". ${ }^{23}$

Thirdly, there was an urgent need to find an answer to the practical question of whether measures to restrict the participation of foreign athletes in matches were legitimate in the light of the goals of the EAEU Treaty. At this point the EAEU Court formulated its position as follows, "Restrictions on working activities in the form of opportunities to compete are prohibited. The fact that these provisions do not apply to the recruitment of players, which is not restricted, but to the club's ability to field them in official matches, does not matter. Since the participation in such matches is the main goal of a professional player's activity, the rule that restricts such participation also limits the right of an athlete to get a job" (para 4 of part III "Conclusions of the Court"). ${ }^{54}$

It should be noted that, unlike the CJEU, the EAEU Court has not directly or inter alia addressed the issue of the right of sports federations to independently establish and determine normative rules in a particular sport. Nevertheless, the judicial decision made on foreign athletes originating from the EAEU States undoubtedly has an impact on the regulation of sports by sports federations when they determine quotas in respect of foreign players.

In its Advisory opinion, the EAEU Court recalled that in accordance with para.13 of the Regulation on the Eurasian Economic Commission (Annex 1 to the 2014 Treaty), "the Commission's decisions are ... binding on the member States, they make part of the Union law and are subject to direct application in the territories of the member States" (para.7 of part III "Conclusions of the Court"). ${ }^{55}$ Consequently, the EEC Decision No. 47 of 11.5.2017 is of a regulatory nature. This wording implies the

${ }^{53}$ Union Royale belge des Sociétés des Football Association ASBL v. Jean-Marc Bosman, Royal Club Liègeois SA v. Jean-Marc Bosman and Others and Union des Associations Européennes de Football (UEFA) v. Jean-Marc Bosman, European Court of Justice, Case C-415/93, Judgment of 15.12.1995, p. 0, para 83, available at: http:/ / eur-lex.europa.eu/legal-content/EN/TXT/ PDF/?uri=CELEX:61993CJ0415\&rid=1 [last accessed 10.6.2020].

\footnotetext{
${ }^{54}$ For more information, see supra note 52.

55 For more information, see supra note 52.
} 
need to bring the national legislation of the member States in line with the requirements contained in this Decision of the Commission. Back in December 2018, Russia could have revised its national policy in the sphere of professional activities aimed at creating the conditions for training Russian athletes that allowed the keeping of quantitative restrictions on the participation of foreign players in matches, or it could have challenged the EEC Decision No. 47 in the EAEU Court on the basis of subpara.1, para.39 of the Statute of the EAEU Court.

Further events in connection with the quotas for foreign athletes in Russian football developed according to the first scenario. First, the Order of the Russian Ministry of Sports of 13.2.2019 No. 109 "On amendments to the Order of the Ministry of Sports of 14.7.2015 No. 732 "On the restrictions on the participation of athletes who are not eligible to play for sports teams of the Russian Federation, all-Russian sports competitions in football" abolished the quantitative restrictions against Belarusian athletes: an exception to the general restriction was made for "foreign nationals who are citizens of the Union State, formed by the Russian Federation and the Republic of Belarus, provided that these citizens have the right to play for national football teams of the Republic of Belarus" (para 1(a)). ${ }^{56}$

Later, the Order of the Russian Ministry of Sports No. 1022 of December 3, 2019 made additional changes to Order No. 732 of 14.7.2015. The existing exception to the general rule, which applied to foreign citizens of the Union State formed by the Russian Federation and the Republic of Belarus, was supplemented by the mention of "citizens of the member States of the Eurasian Economic Union who have the right to play for the sports teams of the member States of the Eurasian Economic Union" (para.1). ${ }^{57}$ These amendments entered into force on August 1, 2020.

${ }^{56}$ Order of the Russian Ministry of Sports of 13.2.2019 No. 109 "On amendments to the Order of the Ministry of Sports of 14.7.2015 No. 732 "On the restrictions on the participation of athletes who are not eligible to play for sports teams of the Russian Federation, all-Russian sports competitions in football", available at: http:/ /www. consultant.ru/document/cons_doc_LAW_182960/ [last accessed 10.6.2020].

57 Order of the Russian Ministry of Sports No. 1022 of 3.12.2019, available at: https:/ / rg.ru/2020/01/16/minsport-prikaz1022-site-dok.html [last accessed 10.6.2020]. 
The development of events in Russian football after the Advisory opinion of the EAEU Court of 7.12.2018 suggests that in the near future quantitative restrictions on professional athletes- citizens of the Member States of the Eurasian Economic Union should also be lifted in all-Russian competitions in other sports, which would fully comply with the letter and spirit of the EAEU Treaty of 2014.

Thus, it can be noted that the entry of a State into an integration association entails significant changes in the system of regulating relations in the field of sports. On the one hand, the practice of the EU and EAEU Courts testifies to the fact that opportunities for athletes' rights protection, and primarily labour rights, are expanding. On the other hand, the normative sources of such regulation are diversified. The formation of the law of integration associations should be taken into account both by national governments when developing legislation in the field of sports and by sports organizations in their rules and regulations. The participation of integration associations in the regulation of relations in the field of sports undoubtedly has an impact on the scope of the normative powers of sports organizations (both national and international), but it does not negate such a principle as the autonomy of sports.

\section{CONCLUSIONS}

Summing up, it is necessary to underline that one of the new functions of the courts of integration associations, to which the Member States have delegated the power to interpret the constituent acts of these associations, is the function of "filling in gaps and removing ambiguities, as well as correcting unsuccessful provisions of an international treaty". ${ }^{88}$ The CJEU and the EAEU Court actively use such powers, making a significant contribution to the development of integration processes in the regional association within which they operate.

The sphere of sports activities is characterized by such a distinctive feature as the autonomy of sport. In accordance with this principle, not

58 A. Ispolinov, Sudy regionalnyh integratsionnyh ob'edineniy (na primere Suda ES i Suda EAES) (Courts of regional integration associations in the system of international justice (on the example of the Court of the EU and the Court of the EAEU), Moscow: Yustitsinform, 2018, p. 20. 
all public relations arising in the field of sport are subject to regulation by States. On the contrary, a considerable part of the regulatory norms are created by sports organizations autonomously without the participation of States and interstate associations. This circumstance should be taken into consideration when interpreting the rules governing the sports sphere.

The Court of Justice of the European Union, known as the Court of Justice of the European Communities from 1958 to 2009, made more than thirty decisions in the field of sport, in which it differentiated between issues in which the sports movement undoubtedly retains its autonomy, and the labour (economic) activities of athletes, which are subject to the Community (Union) law. The Court of the Eurasian Economic Union is a much younger court, which started its activity only back in 2015. However, when interpreting issues of professional sports activities, the EAEU Court does not start from a zero point. It has the opportunity of taking into account the legal arguments and conclusions of the court of another integration association on similar issues. Hopefully, the trend that has emerged in the EAEU Court when rendering advisory opinions "to request not only the opinion of the authorized bodies of the Member States, but also that of the academic community" will definitely contribute to this process. ${ }^{59}$

With the emergence of the law of integration associations, the problem of regulating sports is supplemented by new aspects. There is a need to determine the hierarchy of normative orders formed at the level of integration associations, individual States, as well as sports federations that administer specific sports. This brings about legal conflicts in the resolution of which the judicial institutions of integration associations play a significant role. The practice of the CJEU and the EAEU court testify to it convincingly. It is noteworthy that the inclusion of these courts applying the law of integration associations to resolve sports disputes is due to such a problem as the formation of a single labour market. Unlike the CJEU, the EAEU Court in its practice did not directly address the

59 A. Ispolinov, Sud EAES o sporte i legionerah primenitel'no k evraziyskoy integratsii (The EAEU Court on sports and legionnaires in relation to the Eurasian integration), 2018, available at: https://zakon.ru/blog/2018/12/19/sud_eaes_o_sporte_i_o_legionerah_primenitelno_k_ evrazijskoj_integracii\#comment_481495 [last accessed 10.6.2020]. 
problem of the scope and limits of the rule-making powers of sports federations in regulating certain aspects of professional sports. Instead it focused on the issue of the ability of States to impose certain restrictions in areas affected by interstate integration. Nevertheless, there is no doubt that the problem of sports autonomy is gaining a new meaning in the context of the development of integration structures, and the content of this autonomy is now determined not only by the interaction of sports organizations with States, but also by the regulatory impact made on the former and the latter by the integration associations. 